UDC 378.147

https://doi.org/10.52058/2786-4952 -2021-5(5)-28-35

Bilonozhko Nataliia Elikovna Candidate of Pedagogical Sciences, associate professor of Foreign Languages Department, Taras Shevchenko national university of Kyiv, Volodymirska St., 60, Kyiv, tel. (044) 239-33-02, e-mail: natalia--bilon@ukr.net, https://orcid.org/0000-0003-3192-5615

\title{
SOME ASPECTS OF THE ESP QUALITY OF TEACHING IN THE PROCESS OF INTERNATIONALIZATION
}

Abstract. The focus of the article is on the process of internationalization of the ukrainian universities and the role of English for specific purposes which is considered as a platform for developing Key Competences for Lifelong Learning 2021. It is underlined that the international component of competence-oriented education requires new and innovative forms of English for specific purposes teaching and learning. That is why the participation of ESP teachers in the international projects, one of which is English for Universities British Council Ukraine and Ministry of Education and Science of Ukraine, is of great importance. It is emphasized that such projects have the great influences upon the quality of education in general and ESP teaching in particular, enhance using of the new methods of the professional language competence development. The definitions of ESP as well as its absolute and variable characteristics have been analyzed. This analyses has brought to the conclusion that Needs Analyses is the cornerstone of English for Specific Purposes. Needs Analyses Questionaire as one of the most appropriate research tools to define learners' needs, should be designed in accordance with five specific groups among which is target situation analysis, as well as, objective versus subjective needs analysis, linguistic and discourse analyses. The effectiveness of using Needs Analyses Questionaire is examplified by the results of 5-year-study of the students needs influence of the participation in Academic mobility programs. These results created a valuable bases for the further curriculum design where the students' prospective professional needs, their needs in terms of language skills and some deficiencies in this area had been taken into account. It was concluded that the systematic review of students' needs analyses maintains and improves the quality and efficiency of the educational process. Sharing teaching experience while participating in the international educational projects widens ESP teaching horisons, gives a solid background for building strong quality assurance system as a key to provide high-quality education.

Keywords: internationalization, quality of education, language competence, English for specific purposes, Needs analyses 
Білоножко Наталія Еліковна кандидат педагогічних наук, доцент кафедри іноземних мов Київського національного університету імені Тараса Шевченка, вул. Володимирівська 60, м. Київ, тел.: (044) 239-33-02, e-mail: natalia--bilon@ukr.net, https://orcid.org/0000-0003-3192-5615

\section{ДЕЯКІ АСПЕКТИ ЯКОСТІ НАВЧАННЯ АНГЛІЙСЬКОЇ МОВИ ЗА ПРОФЕСІЙНИМ СПРЯМУВАННЯМ У ПРОЦЕСІ ІНТЕРНАЦІОНАЛІЗАЦІЇ УНІВЕРСИТЕТІВ}

Анотація. У центрі уваги статті - процес інтернаціоналізації українських університетів та роль англійської мови за професійним спрямуванням, яка розглядається як платформа для розвитку ключових компетентностей в умовах безперервної освіти - 2021. Підкреслено, що міжнародний компонент компетентнісно-орієнтованої освіти вимагає інноваційних підходів до викладання англійської мови за професійним спрямуванням. Участь викладачів у міжнародних освітніх проектах, таких як "Англійська мова для університетів" від Британської ради в Україні та Міністерства, освіти і науки України, має велике значення, оскільки сприяє підвищенню рівня якості освіти загалом і викладання англійської мови за професійним спрямуванням зокрема. Проаналізовано визначення англійської мови за професійним спрямуванням та іii абсолютні і змінні характеристики. Було обгрунтовано, що аналіз потреб студентів $\epsilon$ наріжним каменем викладання англійської мови за професійним спрямуванням. Підкреслено, що анкета для аналізу потреб є одним із найбільш відповідних дослідницьких інструментів для визначення потреб студентів і має бути розроблена відповідно до п'яти основних груп: аналіз цільової ситуації, аналіз об'єктивних та суб'єктивних потреб, лінгвістичний та дискурсивний аналізи. Ефективність використання анкети аналізу потреб підтверджується результатами 5-річного вивчення впливу участі студентів в програмах академічної мобільності на їхні потреби у навчальному процесі з іноземної мови. Ці результати створили цінну основу для подальшої розробки навчальних програм, де було враховано перспективні професійні потреби студентів та їхні потреби у розвитку мовних компетентностей. Зроблено висновок, що систематичний аналіз потреб студентів підтримує та підвищує якість та ефективність навчального процесу. Обмін викладацьким досвідом під час участі в міжнародних освітніх проектах розширює горизонти викладання англійської мови за професійним спрямуванням, дає міцне підгрунтя для побудови потужної системи забезпечення якості освіти.

Ключові слова: інтернаціоналізація, якість освіти, мовна компетентність, англійська мова за професійним спрямуванням, аналіз потреб

Introduction. The system of Higher education in Ukraine undergoes valuable transformations as a result of intensive process of internationalization. According to M. Stepko, there are four driving forces under the influence of which transformations 
occur. The first one is the growth of education needs; the second is the diversification of types of higher educational institutions; the third is the impact of information and communication technologies in all aspects of learning; the fourth is globalization, which affects how we teach, learn, study, explore and communicate [3].

This opinion is supported by J. Knight, who underlines that international, intercultural and global dimension are three terms that are intentionally used as a triad. These three terms complement each other and together depict the richness in the breadth and depth of internationalization [10].

Internationalization of higher education is a process of systematic integration of the international component into educational, research and public activities of higher education institutions. International cooperation in the sphere of education has become an important tool of achieving the higher standarts in quality of education, defining and developing competences that are challenging for the young generation.

According to European Proposal for a Council recommendation on Key Competences for Lifelong Learning there have been identified eight key competences needed for personal fulfilment, a healthy and sustainable lifestyle, employability, active citizenship and social inclusion:

- Literacy

- Multilingualism

- Numerical, scientific and engineering skills

- Digital and technology-based competences

- Interpersonal skills, and the ability to adopt new competences

- Active citizenship

- Entrepreneurship

- Cultural awareness and expression [18].

To develop such students' competences it it is necessary to provide high-quality education for them, to facilitate their mobility throughout Europe.

First of all the developed foreign-language communicative competence of the future specialist is the key to successfully overcoming the barrier in the further professional communication, as well as a source of mutual understanding between business partners and their productive business cooperation. It is noteworthy that competence-oriented education requires new and innovative forms of English for specific purposes teaching and learning, the development and implementation of which currently involves the international component.

Internationalization of higher education in Ukraine reveales the new English for specific purposes dimension. The Law of Ukraine "On Higher Education" states that the main directions of international cooperation of universities are participation in international educational and scientific programs, the creation of joint educational and scientific programs with foreign higher educational institutions, scientific institutions and organizations [1]. In this context one should mention the British Council English for Universities project that contributes into the process of internationalization of the universities, quality of education in the field of ESP teaching.

According to Simon Williams, this project is one of the flagship programmes, 
achieving positive, transformational and sustainable change in the quality of teaching and learning of English in higher education institutions, and in the level of English, so that university teaching staff can fully participate in international exchange and collaboration, and students can graduate with more employable skills and greater ability to read the world around them. (5, p.11)

The Teachers of Foreign Language departments of 21 Ukrainian universities inhance their professional skills through a variety of activities and trainings within the framework of the English for Universities project, including:

ATE (Academic Teaching Excellence aimed at improving English Skills at delivering lectures and practical classes on specialist subjects through English as medium of instruction);

EAP (English for Academic Purposes - Improving English Language Teaching Abilities for Academic Purposes for Masters Students);

CiVELT (English for Specific Purposes) - the skills improvement in ESP teaching;

ESP Module Design - Improvement of professional skills in Module design, creating ESP programs;

English for Academics - Improving the skills of writing scientific articles, developing thematic presentations.

Considering the language competence of future specialists the special attention should be paid to CiVELT as it covers different areas of ESP teaching and encourages to have deeper insight into its methodology.

English for Specific Purposes. The ESP problems, the development of foreign language communicative profesional competence have been considered in the works of A. Waters, T. Hutchinson, T. Dudley-Evans, K. Westerfield, O. B. Tarnopolsky, O. G. Polyakov, O. P. Bekonya, V. D. Borschovetska, A. I. Gordeeva, T. M. Korzh, G. A. Grinyuk, T. M. Kameneva, O. P. Petrashchuk, O. M. Sereda and others.

The definitions of English for Specific Purposes are different. According to Rod Bolitho and Richard West, who are experts UK consultants in English for Universities project, ESP is a branch of English language teaching (ELT) concerned with teaching the language needed for a particular purpose. It is devided into English for Academic Purposes (EAP) and English for Occupational Purposes (EOP) (5, p.7). The emphasis upon 'the language needed for a particular purpose' is also in the definitions of A. Waters, T. Hutchinson and T. Dudley-Evans. Many researchers considering the characteristics of Dudley-Evans' definition of ESP, emphasized on its absolute and variable characteristics, namely:

\section{Absolute Characteristics of ESP:}

- ESP is designed to meet specific needs of the learners.

- ESP makes use of underlying methodology and activities of the discipline it serves

- ESP is centered on the language appropriate to these activities in terms of grammar, lexis, register, study skills, discourse and genre. 


\section{Variable Characteristics of ESP:}

- ESP may be related to or designed for specific disciplines;

- ESP may use, in specific teaching situations, a different methodology from that of General English

- ESP is likely to be designed for adult learners, either at a tertiary level institution or in a professional work situation.

- It could, however, be for learners at secondary school level ESP is generally designed for intermediate or advanced students.

- Most ESP courses assume some basic knowledge of the language system.

These characteristics highlight a) ESP connection with the disciplines that future specialists study as their major, b) the age (adult learners mainly) and their level of English, c) the appropriate methodology. However the first point of Absolute Characteristics deals with specific needs of the learners, that can be defined using Needs Analyses questionnaire.

Needs Analyses in ESP is considered to be the cornerstone of English for Specific Purposes.(Simion Minodora Otilia) as well as a key stage in the entire educational process from the determination of aims and objectives to the development of materials. (R. West)

The term 'needs analyses' has been understood differently along the time. At the initial stages of ESP (the 1960s and early 1970), needs analysis consisted in assessing the communicative needs of the learners and the techniques of achieving specific teaching objectives [14]. On the basis of the survey, it was found that the understanding of the process of learning materials' study by the teachers and thetextbook authors did not always coincide with those that students performed. Furthermore, the amount of material they had learned at the lesson was not adequate to the amount of material having been planned by a teacher. Consequently, the natural reaction of the researchers such as J. Rubin, A. Wenden,R. Oxford, A. Chamot, J. O'Malley was to focus on the learners, their ways of learning a language, that were understood as strategies [12, 13, 15]. So in the 1980s the focus of the teachers and researchers began to be directed upon the way the learners aquired knowledge, what made a learner to be successful, what were the strategies of good language learners. It was natural that also the focus of needs analysis was turned towards the learners' preferred learning styles and strategies [11]. R. West described five types of Needs Analyses Aproaches (target situation analysis, deficiency analysis, strategy analysis, means analysis, language audits), where the learning strategies are incorporated into it [15]. Nowdays the idea of learning strategies, learning styles, the ways of strategic competence formation is highly developed as well as understanding of needs analyses became more complex so they have different aims and different implementation but both contribute to learner-centered approach.

The aim of straregic competence development is the improvement of students' language progress using different learning strategies such as metacognitive, cognitive, memory, social and affective ones. 
The aim of Needs Analyses is to gather information about the learners at defining the target situation and environment of studying ESP (Simion Minodora Otilia, 2015).

Duddley-Evans and St. John (2009) identified eight components of Needs Analysis and organized them into five groups such as:

1) target situation analysis and objective needs analysis (e.g. tasks and activities learners will use English for;

2) linguistic analysis, discourse analysis, genre analysis, i.e. knowledge of how language and skills are used in the target situations;

3) subjective needs analysis, i.e. learners'wants, means, subjective needs factors that affect the way they learn (e.g. previous learning experiences, reasons for attending the course, expectations)

4) present situation analysis for the purpose of identifying learners' current skills and language use;

5) means analysis, i.e. information about the environment where the course will run [6].

All these components should be taken into account while designing Needs Analyses questionaire, which is considered to be one of the most appropriate research tools to define learners' needs. Answering the questions of it students are encouraged to analyse the learning process, materials, future job skills and so on. As experience shows such insight into their study motivates students, widens their understanding of the learning process, raises self-confidence and responsibility for their own study. All these factors lead to the development of students autonomy that gives them the opportunity to operate successfully in the learning environment.

The following table examplifies it by presenting 5-year-study of influence of the students participation in Academic mobility projects based on the results of Needs analyses questionnaire and the way they have been solved in the teaching process:

Table 1

\section{№ Faculty}

1. Faculty of Physics

2. Faculty of Physics

\section{Students' needs and their solutions in the teaching context}

Needs

Motivation

letter

To study more

the

\section{Solutions}

Module in writing was extended and included CV, motivation letter, cover letter, letter of interest.

Together with the students math formulas chart was made up; pronunciation of subject teachers reviewed it and added some more math formulas formulas.

3. Faculties of To be prepared 1) 2015 - sharpening of students presentation Physics, Chemistry, Institute of to take part at skills through conducting conference simulation in High technologies. the international the classroom with the second year students; conferences 2) 2016, 2017 - real-life conferences for all the students of the faculty; 2018, 2019 - conferences of the students for three 
faculties;

2019, April 22 - the first students conference

"Science in my life" devoted to the International

Earth day.

2019 May - autonomous conference in

Astronomy organized by the students who took part in the 2015 conference.

2021 - on line Earth Day conference with more than 80 students participated in it.

4. Faculty of Transcript of Chemistry records translation

5. Faculties of Physics and Chemistry
To learn more about Nobel Laureates
The bank of the samples of different documents has been created on the bases of Mobility office consultations; the list of subjects has been made up by the students, subject teachers and English teachers.

The lessons of Nobel Prize organization have been used and listening exercises have been developed.

The results obtained from the students responses' analyses present a valuable bases for the further curriculum design where the students' prospective professional needs, their needs in terms of language skills and some deficiencies in this area will be taken into account. In addition, analysing the students' needs and determining the objectives of the language course enables teachers to use effectively this powerful tool in their professional context, achieving excellence in teaching.

So, Needs analysis in ESP is the step in developing the curriculum content, methods of teaching, materials design. It leads to inhancing learners' motivation and success in foreign language professional communicative competence development. The international context of sharing teaching experience, participation in English for Universities project widens ESP teaching horisons, gives a solid background for transformatonal change in ESP curricular design.

Conclusions. The process of internationalization in Ukraine deals with the new demands to the quality of higher education, especially in the formation of language competence as one of the constituences to develop effectively the Key Life Competences of 2021. It stimulates the appearance of new educational projects and creates an international environment for English for specific purposes teacher training. In this context ESP curriculum design based on Needs Analyses is of great importance to develop skills and competences of the students that will help them operate successfully at the labour market.

\section{References:}

1. Zakon Ukraïni «Pro vishhu osvitu» [The Law of Ukraine "On Higher Education"].(n.d.). zakon.rada.gov.ua. Retrieved from http://zakon5.rada.gov.ua/laws/show/1556-18 [in Ukrainian].

2. Kozievs\&apos;ka, O. (2012). Strategiï internacionalizaciï vishhoï osviti: mizhnarodnii dosvid ta ukraïns\&apos;ki perspektivi [Strategies of internationalization of higher education: international experience and Ukrainian prospects]. Vishha shkola - Higher school, 7, 30-39 [in Ukrainian]. 
3. Stepko, M. (2013). Svitovi tendenciï rozvitku sistem vishhoï osviti ta problemi zabezpechennja jakosti j efektivnosti vishhoï osviti v Ukraïni [World trends in the development of higher education systems and problems of ensuring the quality and effectiveness of higher education in Ukraine]. Vishha shkola - Higher school, 7 [in Ukrainian].

4. Stankevich, I. V. (2015). Sutnist\&apos; ponjattja «jakist\&apos; vishhoï osviti» v suchasnih umovah rozvitku [The essence of the concept of "quality of higher education" in modern conditions of development]. Ecomomic Annals-XXI - Ecomomic Annals-XXI Retrieved from http://soskin.info/userfiles/file/2015/9-10_2015/Stankevych.pdf [in Ukrainian].

5. Bolitho R., West R. (2017) Internationalization of Ukrainian Universities/ R. Bolitho and R. West ; British Council, Ukraine, English for Universities Project. - К. : Сталь. - 130 p.

6. Duddley-Evans, T., and M. J. St John (2009), Development in English for Specific Purposes: A Multidisciplinary Approach, Cambridge: CUP.

7. Dudley-Evans T. (2001). English for specific purposes. In: Carter, R., Nunan, D. (Eds.), Teaching English to Speakers of Other Languages / T. Dudley-Evans. - Cambridge University Press, Cambridge, 2001, 131-136.

8. European Proposal for a Council recommendation on Key Competences for Lifelong Learning./Available at: ttps://ec.europa.eu/education/sites/education/files/recommendationkeycompetences-lifelong-learning.pdf

9. Gatehouse Kristen. Key Issues in English for Specific Purposes (ESP) Curriculum Development. / Available at: http://iteslj.org/Articles/GatehouseESP.Html

10. Knight J. (2015). Updating the definition of Internationalization. / International Higher Education. Available at: https://ejournals.bc.edu/ojs/index.php/ihe/article/viewFile/7391/6588

11. Mohammadi V., Mousavi N. (2013). Analyzing Needs Analysis in ESP: A (re) modeling./ International Research Journal of Applied and Basic Sciences.Vol. 4 (5).

12. Oxford, R. L. (1990). Language learning strategies: what every teacher should know. Boston, Massachusetts: Heinle\&Heinle Publishers.

13. O\&apos;Malley, J; Chamot, A (1990). Learning Strategies in Second Language Acquisition. Cambridge University Press.

14. Otilia Simion Minodora, (2015) Needs Analysis in English for specific purposes / Annals of the „Constantin Brâncuşi” University of Târgu Jiu, Economy Series, Issue 1, volume II / Avaliable at: http://www.utgjiu.ro/revista/ec/pdf/2015-01.Volumul \%202/08_Simion.pdf

15. Rubin, Joan. (1975). What the good language learner can teach us. TESOL Quarterly. 9 (1): 41-51.

16. West R. (1994). State of the art article - needs analysis in language teaching. Language Teaching, 27, 1-19

17. Westerfield K. (2010) An Overview of Needs Assessment in English for Specific Purposes. Best Practices in ESP ETeacher Course / K. Westerfield. - University of Oregon.

18. Why are key competences and basic skills important?. / Available at: https://ec.europa.eu/education/policies/school/key-competences-and-basic-skills_en 